\title{
Challenges and Prospects of Applying the Paradigm of Sustainable Development to the Eastern Europe Economy
}

\author{
TETIANA KULINICH ${ }^{1}$, NATALIA YAKIMENKO-TERESCHENKO ${ }^{2}$, ALLA MELNYK $^{3}$, ALLA $^{2}$ \\ VASINA $^{4}$, VIKTORIIA ADAMYK ${ }^{5}$ \\ ${ }^{1}$ Department of Management of Organizations, Lviv Polytechnic National University, Lviv, \\ UKRAINE \\ ${ }^{2}$ Department of Economic Analysis and Accounting, National Technical University "Kharkiv \\ Polytechnic Institute", Kharkiv, UKRAINE \\ ${ }^{3}$ Department of Management, Public Administration and Personal, West Ukrainian National \\ University, Ternopil, UKRAINE \\ ${ }^{4}$ Department of Management, Public Administration and Personal, West Ukrainian National \\ University, Ternopil, UKRAINE \\ ${ }^{5}$ Department of Management and International Entrepreneurship Department, Lviv Polytechnic \\ National University, Lviv, UKRAINE
}

\begin{abstract}
The paradigm of sustainable development for the economy of Eastern Europe needs detailed research challenges and prospects in Global Sustainable Development Goals implementation by 2030. The main section of the study shows the results determining the position of Eastern European countries on the levels of implementation of the sustainable development concept. The purpose of the study is to analyze existing one's challenges and prospects of applying the paradigm of sustainable development to the economy of Eastern Europe, by evaluated using a synthetic indicator of development, SDG Index and Spillover Index, to obtain and promote the goals of sustainable development. Research methods: comparative analysis; statistical analysis; systematization, generalization. Over the analyzed period, the situation of all Eastern European countries has improved due to the gradual implementation of sustainable development goals. However, the current situation is not beneficial in Eastern European countries, but the some of them (for example Slovenia and Czech Republic) are very close to completing this status. During analyzed period, a reasonable situation was observed in Estonia, Hungary, Slovakia, Poland, Lithuania, Latvia and Croatia. Despite the significant progress Bulgaria and Romania continue to exist at a disadvantage. The most popular in Eastern Europe are financial resources to support small and medium-sized companies, research and innovation, and a low-carbon economy. As a result of the research, it was found that this analysis can provide further motivation and incentives for appropriate action by Eastern European countries to address existing calls. In Eastern Europe, sustainable development should be seen as a goal of development, no less important, namely to reduce contrasts in the quality of life of the population compared to Western European countries.
\end{abstract}

Key-Words: - Sustainable Development, Sustainable Development Goals, Eastern European Countries, SocioEconomic Development, Synthetic Development Indicator, Paradigm of Sustainable Development.

Received: March 26, 2021. Revised: August 1, 2021. Accepted: August 9, 2021. Published: August 24, 2021.

\section{Introduction}

Modern economic realities are shifting faster than political ones, and economic interdependence between countries is becoming more pronounced at the international and regional levels. The paradigm of sustainable development has become the basis for the formation of state programs of many countries, regardless of their level of development. The World Commission on Environment and Development considers sustainable development to be a dynamic forward-looking approach to resource use, investment, technological and institutional development [1].

According to the position United Nations General Assembly the goals of sustainable development should be "action-oriented, concise and easy to communicate, limited in numbers, ambitious, global in nature and common to all countries, taking into account different national realities, prospects and levels of growth in accordance with nationwide rules and priorities" [2].

At the same time, the application of the paradigm of sustainable development at the state level is a 
difficult problem. Accomplishing the sustainable development goals involves significant funds from various sources and attracting additional resources. Therefore, the ability of government to attract, allocate and effectively use appropriate sources of funding, develop strategies and apply tools is an important component of implementing and realizing Goals of Global Sustainable Development. The development of its own sustainable development paradigm should take into account legal systems, socio-economic and environmental conditions, as well as the consequences and restrictions that may hinder the application of selected tools [3].

The crisis caused by global financial problems, as well as the COVID-19 pandemic, has changed the vector of investment and limited investment in individual countries and regions. An example of a response to such changes is the actions of the European Commission, which has developed and implemented different initiatives to promote investment (Juncker's plan), as well as promoted financial initiatives of the EU Fund [4].

The need for the formation and implementation of the sustainable development paradigm at the level of an individual state is due to the idea of economic, social and environmental components harmonization. At the same time, the ecological component is the most important and consists in solving problems of environmental protection, development and implementation of measures to minimize and mitigate the effects of global climate change, conservation of national natural resources for coming generations.

The practical significance of the results of the study is to develop measures to implement the paradigm of sustainable development and address the impact of practical steps of sustainable development on the economies of Eastern Europe, which provides "way of society in which meeting the needs of future generations" [1].

The aim of the study - analysis of existing ones challenges and prospects of applying the paradigm of sustainable development to the economy of Eastern Europe, by evaluated using a synthetic indicator of development, SDG Index and Spillover Index, to obtain and promote the goals of sustainable development.

Research objectives of the article:

1. Analyze SDG Index and Spillover Index in Eastern Europe for the period 2018-2020 and determine Threads on the development of sustainable development goals.

2. Conduct research on indicators that analyze evolution in the implementation of sustainable development concept in Eastern Europe.
3. Identify the challenges and prospects of applying the paradigm of sustainable development to the economy Eastern Europe to help bridge the funding gap for sustainable development goals.

4. Display statistics on the allocation of resources of financial tools for the operational programs.

\section{Literature Review}

Because of the crisis of global environmental problems in the last half of the 20-th century, as well as the outline of United Nations (UN) conferences on environmental protection, a view was formed on a sustainable balance among the individual mechanisms of the international environmental and socio-economic system. According to Raszkowski \& Bartniczak the sustainable development paradigm includes an approach to creating a model of economic development, which results in harmony with the environment and effectively meets the society needs [5].

The concept of sustainable development is founded on three main mechanisms: economic growth, social integration and environmental protection. The beginning of the concept of sustainable development took place in September 2015, as a process of approval at a meeting of the UN General Assembly "Transforming our world: Agenda for sustainable development until 2030" [6]. The Agenda of Sustainable Development is a world transformation program that predicts the eradication of poverty, the guarantee of a distinguished life for all, and peace by 2030, one of the major challenges of the modern world [7].

As stated by the Organization for Economic Cooperation and Development (OECD), private and public earnings, particularly in positive market conditions, should be enough to meet the requirements of the key investment groups holding the convention [8]. That is why, in order to accomplish the goals of sustainable development in the context of the paradigm, it is necessary to organize the work of the international financial community, the private (individual) financial sector, as well as the public financial sector.

Eastern European countries that support the sustainable development goals, as a part of their initiatives seek to implement economic solutions based on the concept of sustainable development, which is defined in social, economic and environmental terms $[9 ; 10]$. Soini \& Birkeland recommended to include cultural factors as a fourth element of the Sustainable Development Goals (SDGs) [11]. 
Shrithongrung \& Kriz believe that at the stage of implementation of the SDGs, their implementation should be supported by financing sustainable development [12]. At the same time, the focus of the sustainable development paradigm should be based on the attractiveness of the state and/or region, as a more important form for investment and future development to be achieved by the state [13]. For Eastern European countries, both innovation and education are central, as main determinants of the competitiveness and economic convergence [14]. Donaires et al. believe that the implementation of sustainable development policies of individual states and areas should be carried out at three stages: individual, organizational and global [15]. At the same time, the government should regulate the sustainable development at the national level, which concerns the socio-economic level [16].

In 2004, at the time of the accession of the new members to the EU (Poland, Czech Republic, Lithuania, Latvia, Estonia, Slovakia, Slovenia and Hungary), the paradigm of sustainable development of the Eastern European countries was approached as an ambitious task of development. Bulgaria and Romania joined the EU in 2007, and Croatia in 2013. Because at this stage the countries of Eastern Europe are facing existing socio-economic problems (high unemployment rate, high infrastructural backwardness, lack of good transportation with other parts of Europe, gradual emigration, comparatively low households purchasing power, imperfect regulation, non-effective environmental values, etc.). An important component of the implementation of the concept of sustainable development, primarily to catch up with Western Europe, was close collaboration among the public and private sectors, as well as non-governmental agencies $[17 ; 18 ; 19]$.

About ten years after the accession of most Eastern European countries to the EU-members, their conditions has changed significantly, as these countries have made a important leap in their development. Eastern European countries have the maximum level of the Human Development Index (HDI), the countries of the region are gradually becoming attractive for foreign investment, they coped well with the global crisis of 2009-2010, reaching a level of economic growth in GDP above the average in the coming years $[3 ; 20 ; 21 ; 22]$. At the same time, achievements and optimistic features do not mean that countries have reached the best levels of development, as many problems remain unresolved. It is the paradigm of sustainable development that has become particularly important for the countries of Eastern Europe, as its implementation can contribute not only to quantitative but also to qualitative change, covering all aspects of the Global Sustainable Development Goals, including a better environment, advanced social activity and lower poverty, formation of social values, based on equality and tolerance, in addition to ensure better public administration [23].

Considering the paradigm of sustainable development, it is based on meeting the needs of the current generation, but not reducing the needs of coming generations [24]. The natural environment, which is treated in terms of SDGs, remains its basis, the main tool for economic development, prosperity and high quality of life. The fairness of the distribution of goods between generations is one of the most important aspects. That is, the need to preserve natural wealth for coming generations through economic managing of available natural resources, balanced use of its potential, upholding the stability of the environment and resources recycling [25].

Analysis of publications of modern scientists allows us to conclude that the issue of practical impact of the paradigm of sustainable development on the economy, taking into account the integration of national economies into the structure of the world socio-economic space is a relevant and widespread direction in research.

At the same time, the question of the prospects of applying the paradigm of sustainable development to the economies of Eastern European countries remains important and open for further research.

\section{Methods and Materials}

The analysis existing in this research, comprises the eleven countries of the CEE region: Bulgaria, Croatia, the Czech Republic, Estonia, Hungary, Latvia, Lithuania, Poland, Romania, Slovakia and Slovenia. This distinction was the result of a classification provided by the Organization for Economic Co-operation and Development (OECD) and was used in the article [26]. It should be noted that the countries of Eastern Europe, depending on the accepted criteria, also include Belarus, Ukraine, Serbia, Macedonia or Kosovo (not recognized by some countries).

To identify individual features and trends in the implementation of the paradigm of sustainable development and the Global Sustainable Development Goals, the following indicators were used for the countries of Eastern Europe:

Sustainable Development Goals (SDG) Index; Spillover Index. 
The study on the implementation of the Global Sustainable Development Goals by 2030 was conducted on the basis of reports from the European Commission, OECD, UN. The use of the method of comparison and statistical analysis made it possible to distinguish between the challenges and prospects of applying the paradigm of sustainable development to the economies of Eastern Europe. The value of the synthetic development indicator for individual countries was calculated according to the method proposed by Raszkowski, A. \& Bartniczak, B. [5].

The study was grounded on indicators that analyze implementation progress of the concept of sustainable development, covering the countries of Eastern Europe, based on Eurostat data. Indicators corresponding to SDGs objectives 14 and 15 were not comprised in this study due to the lack of statistics for the countries selected for analysis in Eurostat databases.

\section{Results}

The Global Sustainable Development Goals by 2030 are considered vectors of sustainable development at the state level and worldwide. SDG by 2030 consists of 169 tasks, and a system of 240 global indicators has been developed for effective monitoring of the quality of implementation of global tasks. At the same time, the tasks for the implementation of the policy of sustainable development of individual states and regions can be realized only through the general cooperation of all countries of the world.

The SDG Index tracks the performance of countries in meeting 17 sustainable development goals. In 2018, Slovenia, the Czech Republic and Estonia ranked among the countries of Eastern Europe in terms of the effectiveness of the sustainable development goals. During 2019-2020, the leading positions were occupied by the Czech Republic, Estonia and Slovenia, and the last positions were occupied by Romania and Bulgaria. The distribution index measures the transboundary affect that one country exerts on others, which in turn can undermine other countries' ability to achieve sustainable goals. The dissemination index covers the financial, environmental and social implications of trade and consumption, and includes cooperation in security and development. The best indicators are shown by Romania, Bulgaria and Croatia, which show good efficiency and no significant negative consequences, while Lithuania generates significant negative consequences for other countries (see Table 1).

Table 1. The 2018-2020 SDG Index and Spillover Index

\begin{tabular}{|c|c|c|c|c|c|c|c|c|}
\hline \multicolumn{9}{|c|}{ SDG Index } \\
\hline \multicolumn{3}{|c|}{2018} & \multicolumn{3}{|c|}{2019} & \multicolumn{3}{|c|}{2020} \\
\hline Rank & Country & Score & Rank & Country & Score & Rank & Country & Score \\
\hline 8 & Slovenia & 80.0 & 7 & Czech Republic & 80.7 & 8 & Czech Republic & 80.6 \\
\hline 13 & Czech Republic & 78.7 & 10 & Estonia & 80.2 & 10 & Estonia & 80.1 \\
\hline 16 & Estonia & 78.3 & 12 & Slovenia & 79.4 & 12 & Slovenia & 79.8 \\
\hline 21 & Croatia & 76.5 & 22 & Croatia & 77.8 & 19 & Croatia & 78.4 \\
\hline 24 & Slovak Republic & 75.6 & 24 & Latvia & 77.1 & 23 & Poland & 78.1 \\
\hline 26 & Hungary & 75.0 & 25 & Hungary & 76.9 & 24 & Latvia & 77.7 \\
\hline 27 & Latvia & 74.7 & 27 & Slovak Republic & 76.2 & 27 & Slovak Republic & 77.5 \\
\hline 32 & Poland & 73.7 & 29 & Poland & 75.9 & 29 & Hungary & 77.3 \\
\hline 34 & Bulgaria & 73.1 & 32 & Lithuania & 75.1 & 36 & Lithuania & 75.0 \\
\hline 36 & Lithuania & 72.9 & 36 & Bulgaria & 74.5 & 38 & Romania & 74.8 \\
\hline 44 & Romania & 71.2 & 42 & Romania & 72.7 & 39 & Bulgaria & 74.8 \\
\hline \multicolumn{9}{|c|}{ Spillover Index } \\
\hline \multicolumn{3}{|c|}{2018} & \multicolumn{3}{|c|}{2019} & \multicolumn{3}{|c|}{2020} \\
\hline Rank & Country & Score & Rank & Country & Score & Rank & Country & Score \\
\hline 44 & Romania & 93.5 & 42 & Romania & 93.8 & 101 & Romania & 91.6 \\
\hline 34 & Bulgaria & 91.0 & 36 & Bulgaria & 90.1 & 112 & Bulgaria & 85.4 \\
\hline 21 & Croatia & 85.4 & 22 & Croatia & 85.9 & 113 & Croatia & 83.1 \\
\hline 32 & Poland & 84.2 & 29 & Poland & 84.9 & 117 & Poland & 81.8 \\
\hline 26 & Hungary & 80.9 & 25 & Hungary & 81.9 & 124 & Hungary & 77.1 \\
\hline 24 & Slovak Republic & 69.7 & 27 & Slovak Republic & 71.4 & 126 & Slovak Republic & 72.7 \\
\hline 27 & Latvia & 70.0 & 24 & Latvia & 71.9 & 127 & Latvia & 70.4 \\
\hline 13 & Czech Republic & 79.7 & 7 & Czech Republic & 79.8 & 129 & Czech Republic & 69.7 \\
\hline 16 & Estonia & 82.7 & 10 & Estonia & 82.9 & 130 & Estonia & 69.4 \\
\hline 8 & Slovenia & 68.6 & 12 & Slovenia & 70.0 & 142 & Slovenia & 66.4 \\
\hline
\end{tabular}


\begin{tabular}{|l|l|l|l|l|l|l|l|l|}
\hline 36 & Lithuania & 71.6 & 32 & Lithuania & 73.1 & 144 & Lithuania & 65.6 \\
\hline \multicolumn{3}{|c|}{ Source: Compiled by the authors by official data of The Sustainable Development Report [27; 28], SDG }
\end{tabular} Index and Dashboards Report [29]

Eastern European countries perform best in achieving the following sustainable development goals: 1 (Poverty Alleviation) and 7 (Providing access to low-cost, reliable, sustainable and modern energy sources for all). Compared to other regions, such a goal as 16 (promoting a peaceful and open society for sustainable development, ensuring access to justice for all and creating effective, accountable and participatory institutions at all levels) remains problematic due to the relatively high level of perception of corruption in some countries, low freedom of speech or high risk. Low efficiency in implementing goals 12 to 15 ensuring the transition to rational models of consumption and production; taking urgent action to combat climate change and its consequences; conservation and sustainable use of oceans, seas and marine resources in the interests of sustainable development; protection and restoration of terrestrial ecosystems and promotion of their rational use, rational forest use, combating desertification, stopping and reversing the process of land degradation and stopping the process of biodiversity loss requires urgent political attention. Access to basic services and infrastructure covered in particular by Objective 6 (Ensuring accessibility and sustainable management of water resources and sanitation) and goal 7 (Providing access to low-cost, reliable, sustainable and modern energy sources for all), is rapidly improving. In contrast, trends towards goal 15 (Protection and restoration of terrestrial ecosystems and promotion of their rational use, rational forest management, combating desertification, stopping and reversing the process of land degradation and stopping the process of biodiversity loss) and goal 17 (Strengthen the means of implementation and intensify work in the framework of the global partnership for sustainable development) in many countries in the region are stagnating or changing (see Table 2).

Table 2. The Trends of SDG Index 2020

\begin{tabular}{|c|c|c|c|c|c|c|c|c|c|c|c|}
\hline \multirow[t]{2}{*}{ SDG } & \multicolumn{11}{|c|}{ Trends } \\
\hline & 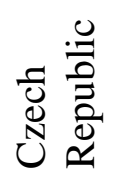 & 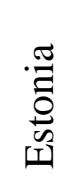 & $\begin{array}{l}\cdot \frac{\pi}{3} \\
\frac{0}{0} \\
\frac{0}{2}\end{array}$ & 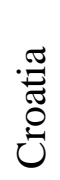 & $\begin{array}{l}\vec{\Xi} \\
\text { ज्ञ } \\
0\end{array}$ & 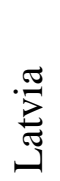 & $\begin{array}{l}\frac{0}{0} \\
\frac{1}{\pi} \\
\frac{0}{0} \\
\frac{0}{2}\end{array}$ & 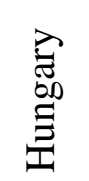 & & 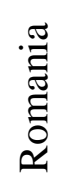 & 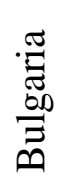 \\
\hline Goal 1: No Poverty & & & & $\uparrow$ & & & & $\uparrow$ & & & 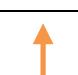 \\
\hline $\begin{array}{lll}\text { Goal 2: } & \text { Zero } \\
\text { Hunger } & & \end{array}$ & & & & & & $\longrightarrow$ & & $\longrightarrow$ & $\longrightarrow$ & & \\
\hline $\begin{array}{lll}\text { Goal } & 3: & \text { Good } \\
\text { Health } & \text { and } & \text { Well- } \\
\text { Being } & & \end{array}$ & & & & & & & & & & & \\
\hline $\begin{array}{ll}\text { Goal 4: } & \text { Quality } \\
\text { Education } & \end{array}$ & & & & & & & & & & & \\
\hline $\begin{array}{l}\text { Goal 5: Gender } \\
\text { Equality }\end{array}$ & & & & & & 4 & & & & & \\
\hline $\begin{array}{lr}\text { Goal 6: } & \text { Clean } \\
\text { Water } & \text { and } \\
\text { Sanitation } & \end{array}$ & & & & & $\uparrow$ & $\uparrow$ & & $\uparrow$ & & & \\
\hline $\begin{array}{l}\text { Goal 7: Affordable } \\
\text { and Clean Energy }\end{array}$ & & & & & $\rightarrow$ & $\uparrow$ & & $\longrightarrow$ & & & \\
\hline $\begin{array}{lr}\text { Goal 8: Decent } \\
\text { Work } \\
\text { Economic } & \text { and } \\
\end{array}$ & 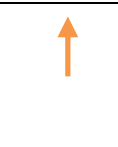 & & & 1 & $\uparrow$ & $\uparrow$ & & 4 & $\hat{\uparrow}$ & & \\
\hline Goal 9: Industry, & & & & & & & & & & & \\
\hline
\end{tabular}




\begin{tabular}{|c|c|c|c|c|c|c|c|c|c|c|c|}
\hline $\begin{array}{ll}\text { Innovation } & \text { and } \\
\text { Infrastructure } & \end{array}$ & & & & & & $\longrightarrow$ & & & $\longrightarrow$ & & \\
\hline $\begin{array}{l}\text { Goal 10: Reduced } \\
\text { Inequalities }\end{array}$ & & & & 0 & $\longrightarrow$ & $\longrightarrow$ & & & & 0 & 0 \\
\hline $\begin{array}{lr}\text { Goal } & 11: \\
\text { Sustainable Cities } \\
\text { and Communities }\end{array}$ & & & & & & & & & & & \\
\hline $\begin{array}{ll}\text { Goal } & 12: \\
\text { Responsible } & \\
\text { Consumption } \\
\text { Production }\end{array}$ & 0 & 0 & 0 & 0 & 0 & 0 & 0 & 0 & 0 & 0 & 0 \\
\hline $\begin{array}{l}\text { Goal 13: Climate } \\
\text { Action }\end{array}$ & 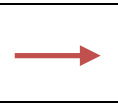 & $\longrightarrow$ & $\downarrow$ & & $\downarrow$ & $\longrightarrow$ & $\downarrow$ & $\downarrow$ & $\downarrow$ & $\longrightarrow$ & $\longrightarrow$ \\
\hline $\begin{array}{ll}\text { Goal 14: } & \text { Life } \\
\text { Below Water } & \\
\end{array}$ & 0 & $\longrightarrow$ & $\longrightarrow$ & & & $\longrightarrow$ & 0 & 0 & & & \\
\hline $\begin{array}{l}\text { Goal 15: Life on } \\
\text { Land }\end{array}$ & 1 & 4 & $\uparrow$ & $\uparrow$ & $\uparrow$ & $\uparrow$ & 4 & 4 & $\uparrow$ & $\uparrow$ & 1 \\
\hline $\begin{array}{l}\text { Goal 16: Peace, } \\
\text { Justice and } \\
\text { Institutions }\end{array}$ & & $\uparrow$ & $\uparrow$ & & & $\longrightarrow$ & & 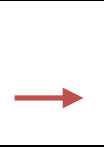 & $\uparrow$ & & \\
\hline $\begin{array}{l}\text { Goal 17: } \\
\text { Partnerships for the } \\
\text { Goals }\end{array}$ & & & & 0 & $\longrightarrow$ & $\downarrow$ & $\longrightarrow$ & 7 & $\longrightarrow$ & $\downarrow$ & $\uparrow$ \\
\hline
\end{tabular}

Source: Compiled by the authors by official data of The Sustainable Development Report [28]

I- Decreasing; $\longrightarrow \quad$ - Stagnating,

- Moderately improving; - On track or maintaining SDG

achievement;

- Information unavailable.

The results of 2020 on trends over time are presented in Table 3. The survey covers 30 countries, including most of the G20 and OECD countries, as well as countries with a population of over 100 million people, this list includes three countries from Eastern Europe, namely Hungary, Poland and Slovenia. There is a discrepancy between the expressed political support for the goals of sustainable development and their integration into the strategic processes of public policy, including national budgets. Sustainable development goals in these countries are integrated into a specific strategy or action plan or sectoral policy. Countries have also designated a focal point or agency responsible for coordinating and implementing sustainable development goals. Countries have also defined a national set of indicators for sustainable development goals, or created special platforms for reporting on the availability of indicators at the national level, which use about 70 to 126 indicators (see Table 3).

Table 3. National government efforts to implement the SDG Index 2020

\begin{tabular}{|c|c|c|c|c|c|c|c|c|c|}
\hline \multirow[t]{2}{*}{ Country } & \multirow{2}{*}{$\begin{array}{c}\text { VNR } \\
\text { Date } \\
\text { submitted }\end{array}$} & \multirow{2}{*}{\begin{tabular}{|c|}
$\begin{array}{c}\text { High-level } \\
\text { statements }\end{array}$ \\
$+/-$
\end{tabular}} & \multirow{2}{*}{$\begin{array}{l}\text { SDG strategy / } \\
\text { SDGs into sectoral } \\
\text { action plans } \\
+/-\end{array}$} & \multicolumn{3}{|c|}{ Budget } & \multicolumn{2}{|c|}{$\begin{array}{c}\text { National } \\
\text { monitoring }\end{array}$} & \multirow{2}{*}{\begin{tabular}{|c}
$\begin{array}{c}\text { Stakeholder } \\
\text { engagement }\end{array}$ \\
$+/$ -
\end{tabular}} \\
\hline & & & & $+/-$ & $\begin{array}{c}\text { overarching } \\
\text { narrative / section } \\
\text { or budget line }\end{array}$ & $\mathrm{DI} / \mathrm{IC}$ & $+1-$ & $\begin{array}{l}\text { No of } \\
\text { indicators }\end{array}$ & \\
\hline $\begin{array}{c}\text { European } \\
\text { Union }\end{array}$ & $\begin{array}{c}\text { not } \\
\text { applicable }\end{array}$ & + & + & + & $\begin{array}{c}\text { overarching } \\
\text { narrative }\end{array}$ & $\begin{array}{c}\text { DI } \\
\text { and IC }\end{array}$ & + & 100 & + \\
\hline Hungary & 2018 & - & + & - & & & + & 83 & + \\
\hline Poland & 2018 & + & + & - & & & + & 126 & + \\
\hline Slovenia & $\begin{array}{c}2017 \text { and } \\
2020\end{array}$ & + & + & + & $\begin{array}{c}\text { overarching } \\
\text { narrative }\end{array}$ & IC & + & 70 & + \\
\hline
\end{tabular}


Source: Compiled by the authors by official data of The Sustainable Development Report [28]

The levels of the Synthetic Development Indicator (SDI) in 2010-2016 were calculated on the base of indicators from the Table 1. The table interprets the indicators and analyzes the situation in terms of the implementation of sustainable development models in eleven Eastern European countries. The introduction of sustainable development in some years was not much more expanded, which is established by the small amount of the coefficient of variation. Diversification has shown a descending tendency, which is confirmed by a decrease in the indicator's level. With each passing year, the analyzed countries approached the benchmark, as shown by the ever-increasing median and minimum value, together with the increase in the maximum value. A very high value of Pearson's linear correlation coefficient indicates insignificant changes in the annual ranking of countries. If the place in the rating has changed, it is preferably in one or two positions (up or down). Slovenia was among leaders during the analyzing period (except in 2011 and 2014 year). Instead in 2011 and 2014, the Czech Republic, which in other years took second place, occupied the leading position and Romania took last place for all analyzed years (see Table 4).

Table 4. Synthetic measure of development (SMD) values, synthetic measures for the distance from the pattern in the years $2010-2016$

\begin{tabular}{|l|c|c|c|c|c|c|c|}
\hline & 2010 & 2011 & 2012 & 2013 & 2014 & 2015 & 2016 \\
\hline BG & 0,339 & 0,333 & 0,349 & 0,359 & 0,367 & 0,387 & 0,385 \\
\hline HR & 0,373 & 0,350 & 0,337 & 0,338 & 0,385 & 0,399 & 0,426 \\
\hline CZ & 0,546 & 0,567 & 0,578 & 0,571 & 0,576 & 0,579 & 0,591 \\
\hline ES & 0,493 & 0,529 & 0,538 & 0,549 & 0,534 & 0,552 & 0,535 \\
\hline HU & 0,437 & 0,439 & 0,448 & 0,457 & 0,475 & 0,503 & 0,507 \\
\hline LV & 0,346 & 0,373 & 0,419 & 0,439 & 0,446 & 0,456 & 0,469 \\
\hline LT & 0,382 & 0,417 & 0,449 & 0,460 & 0,485 & 0,475 & 0,484 \\
\hline Pl & 0,415 & 0,420 & 0,439 & 0,444 & 0,471 & 0,481 & 0,487 \\
\hline RO & 0,309 & 0,312 & 0,316 & 0,320 & 0,328 & 0,322 & 0,342 \\
\hline SK & 0,446 & 0,453 & 0,456 & 0,464 & 0,47 & 0,484 & 0,502 \\
\hline Sl & 0,551 & 0,561 & 0,585 & 0,576 & 0,575 & 0,581 & 0,592 \\
\hline Median & 0,415 & 0,420 & 0,447 & 0,457 & 0,470 & 0,480 & 0,487 \\
\hline Minimum value & 0,310 & 0,312 & 0,316 & 0,320 & 0,328 & 0,322 & 0,342 \\
\hline Maximum value & 0,551 & 0,567 & 0,585 & 0,577 & 0,576 & 0,581 & 0,592 \\
\hline Difference quotient & 0,241 & 0,256 & 0,269 & 0,257 & 0,249 & 0,259 & 0,249 \\
\hline Coefficient of variation (\%) & 18,5 & 19,7 & 19,6 & 18,7 & 16,6 & 16,3 & 15,3 \\
\hline Arithmetic mean & 0,421 & 0,432 & 0,447 & 0,452 & 0,465 & 0,474 & 0,484 \\
\hline Standard deviation & 0,078 & 0,085 & 0,087 & 0,084 & 0,077 & 0,078 & 0,074 \\
\hline $\begin{array}{l}\text { Pearson's linear correlation } \\
\text { coefficient (analyzed year } \\
\text { against the previous year) }\end{array}$ & - & 0,981 & 0,985 & 0,996 & 0,985 & 0,991 & 0,990 \\
\hline \multicolumn{2}{|l|}{} & & & & & & \\
\hline
\end{tabular}

Source: Compiled by the authors by official data of The Eurostat [30] and [5]

Table 5 shows the distribution of financial resources for operational programs by investment; Of course, financial resources were directed to support small and medium-sized companies, which were the most popular among Eastern European countries, followed (remotely) by research and innovation and a low-carbon economy. The panEuropean target was to invest $20 \%$ of low-carbon development programs in financial instruments, but only $9.5 \%$ was reached [31].

Table 5. Allocation of the budget to operational programs on the topic, which is allocated to financial instruments at the end of 2017

\begin{tabular}{|l|c|c|c|c|c|c|}
\hline & R\&D \& I & ICT & SME support & $\begin{array}{c}\text { Energy } \\
\text { efficiency / } \\
\text { renewables }\end{array}$ & $\begin{array}{c}\text { Environmental } \\
\& \text { resource } \\
\text { efficiency }\end{array}$ & $\begin{array}{c}\text { Sustainable } \\
\text { transport }\end{array}$ \\
\hline BG & 10,3 & 0,0 & 36,6 & 7,3 & 11,4 & 0,0 \\
\hline CZ & 1,2 & 0,0 & 51,7 & 3,2 & 9,0 & 0,0 \\
\hline ES & 8,4 & 0,0 & 39,5 & 0,7 & 0,3 & 0,0 \\
\hline
\end{tabular}




\begin{tabular}{|l|c|c|c|c|c|c|}
\hline HU & 29,9 & 42,4 & 34,4 & 24,4 & 0,0 & 0,0 \\
\hline LT & 2,6 & 0,0 & 31,3 & 42,3 & 14,8 & 0,0 \\
\hline LV & 0,0 & 0,0 & 42,7 & 12,3 & 0,0 & 0,0 \\
\hline PL & 7,2 & 0,0 & 25,4 & 9,8 & 0,0 & 0,0 \\
\hline RO & 5,1 & 0,0 & 47,1 & 2,5 & 0,0 & 0,0 \\
\hline SI & 27,7 & 0,0 & 48,3 & 23,8 & 0,0 & 0,0 \\
\hline SK & 0,0 & 0,0 & 17,0 & 14,1 & 3,7 & 3,4 \\
\hline EU 28 & 8,9 & 3,5 & 34,0 & 9,5 & 3,1 & 0,3 \\
\hline Target & 5,0 & 10,0 & 50,5 & 20,0 & 5,0 & 10,0 \\
\hline Total FI & 3667,7 & 468,4 & 11319,7 & 3748,5 & 1089,0 & 189,9 \\
\hline CM Total & 41104,0 & 13308,1 & 33276,3 & 39661,4 & 34993,5 & 58523,8 \\
\hline
\end{tabular}

Source: Compiled by the authors by official data of the European Regional Development Fund [31]

Based on research and review of the subject literature identified challenges and prospects of applying the paradigm of sustainable development to the economy of Eastern Europe (see Fig. 1). Challenges include depletion of natural resources; variations in the financial situation, the emergence of crises; increased rivalry from other European countries and rest of the world; social stratification; comprehensive revitalization of public space and aging population. Prospects for application paradigms of sustainable development for the economy of Eastern Europe are as follows: promotion of a healthy lifestyle, active leisure; enhanced activities of the NGO sector; adaptation of national legislation to EU environmental requirements; allocation from the state budget of significant funds from public sources for ecologically friendly solutions and climate defense, as well as the development of environmental awareness among citizens.

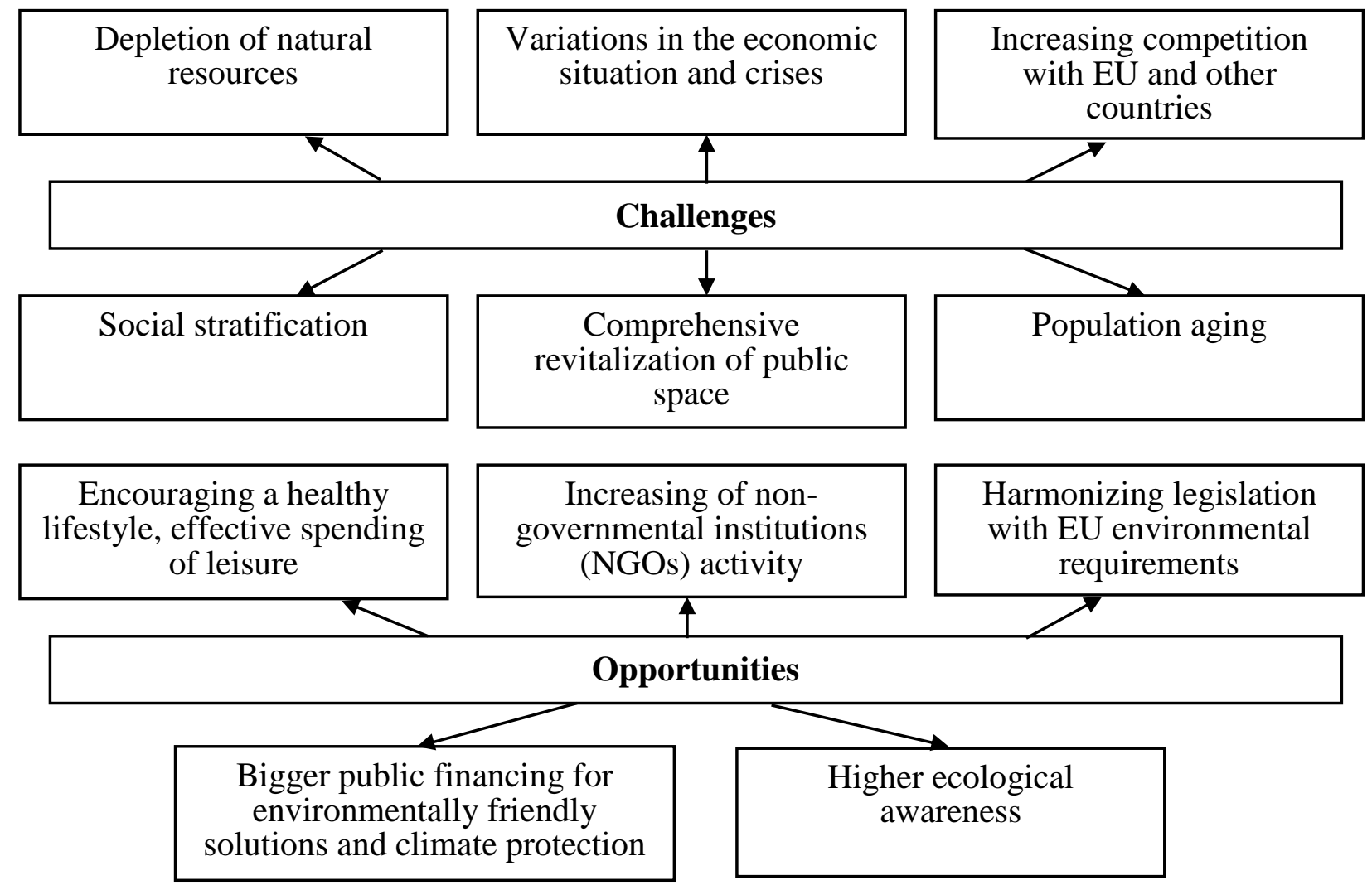

Fig. 1. Challenges and prospects of applying the paradigm of sustainable development to the economy of Eastern Europe

Thus, further overcoming the challenges and prospects of applying the paradigm of sustainable development to the economies of Eastern Europe will provide implementation of sustainable development policies will increase the effectiveness of the functioning of socio-economic systems of states and make more favorable conditions for in- 
depth incorporation of the European economic environment into international community.

\section{Discussion}

The problem of implementing the paradigm of sustainable development in Eastern Europe shows a consistent improvement and upward trend. At the same time, today none of the countries in which the analysis was conducted is included in the group of countries with a favorable trend in the implementation of the SDGs. Some Eastern European countries (for example, Czech Republic and Slovenia) came close to realizing their goals, but remained in the group with other countries (Estonia, Hungary, Slovakia, Poland, Lithuania, Latvia and Croatia). During the study period, a negative situation for the implementation of the SDGs was in Bulgaria and Romania.

The study identified the challenges facing Eastern European countries to achieve sustainable development goals [5; 7]:

1) gradual aging of the population - this problem affects the vast majority of European countries. In this regard, it is recommended that steps be taken to intensify family policy, together with the distribution of childcare allowance already in place in most Eastern European countries.

2) Increasing competition between EU countries and at the global level is also considered a challenge for sustainable development. At the present stage, the activity of competition is growing, especially in the field of attracting new and retaining current investors. One of the ways to solve this problem is to promote and deepen cooperation between the EU countries in general and Eastern Europe in particular, because by joining forces they can strengthen the common competitive position.

3) Constant changes in the economic situation and the impact of the crisis. In this case, the use of scenario-oriented planning, joint development of alternative strategies, the ability to respond quickly to changes and challenges are effective.

4) Social stratification, which reflects the differentiation of society in Eastern Europe into separate social classes and segments of the population. Research shows that achieving the sustainable goals of sustainable development is impossible when a significant part of society is at risk of poverty.

It is also worth adding that the process of depletion of natural resources is usually associated with the expansionist policy of human development. At the same time, in recent years, the countries of
Eastern Europe have been particularly affected by such depletion of resources [24].

Prospects for the application of the paradigm of sustainable development to the economies of Eastern Europe researchers determine favorable changes in the field of education, in relation to the growing social environmental consciousness. Eastern European countries (EU members and nonEU members) are one of the main beneficiaries of funding from EU funds. At the same time, many financial assistance programs are directly aimed at developing and implementing environmentally friendly solutions in the context of the sustainable development paradigm. For the countries of Eastern Europe, such targeted allocation of funds forms a perspective for future development and an opportunity to transfer the national economy to the direction of sustainable development. Adaptation of national legislation to EU standards is a positive component of the process of implementing the paradigm of sustainable development at the national level. Legislative changes in the context of the high environmental standards applied in the EU, such as the reduction of emissions of toxic compounds into the atmosphere, deserve special attention. Solving these problems usually requires significant costs, but ultimately it is expected that countries will contribute to environmental protection and sustainable development [31;32].

The social component is also very important in the implementation of the paradigm and principles of sustainable development. In this context, NGOs are able to stimulate the social development of local communities in individual countries, as well as have the opportunity to receive financial support from European Union funds through grants and targeted funding. In addition, the increasing spread of a healthy and active lifestyle among the population contributes to the gradual improvement of quality of life and its duration. This approach will contribute to the harmonization of relations between humanity, society and the environment $[5 ; 7]$.

Thus, the research conducted by scientists does not provide relevant information on the challenges and prospects of applying the paradigm of sustainable development to the economies of Eastern Europe. We consider it expedient to focus further research in this direction to analyze the challenges and prospects of applying the paradigm of sustainable development to the economies of Eastern Europe. It is now appropriate to take concrete measures to minimize and eliminate future threats, as well as to implement sound policies aimed at conserving and protecting resources, using renewable energy sources and promoting a fair 
distribution of resources between present and future generations.

\section{Conclusion}

As a result of the analysis of challenges and problems of the impact of the application of the paradigm of sustainable development on the economy of Eastern European countries, it was found that the studied countries have untapped prospects. The paradigm of sustainable development is a fundamental basis for the development of a global system that encompasses environmental, socio-economic parameters. Global SDGs are the basis for the formation of strategies and tactics for the development of the modern world, which takes into account global problems and needs by covering social, economic problems and environmental protection. The paradigm of sustainable development allows to form a general approach to the development and implementation of national concepts and public policy in individual countries.

Thus, addressing the challenges and implementing the perspective of applying the paradigm of sustainable development to the economies of Eastern Europe can become a new vector and a means of integrating national economies.

Further research may focus on using the concept of sustainable development of Eastern European countries to facilitate their further integration with the EU and use their experience for potential members of the European Union. The application of innovative, financial and economic approaches to the implementation of the paradigm of sustainable development can be the basis for further $\mathrm{EU}$ enlargement.

\section{References:}

[1] Brundtland, G. Our Common Future: Report of the 1987 World Commission on Environment and Development; United Nations: Oslo, Norway, 1987. pp. 1-59.

[2] United Nations General Assembly, The Road to Dignity by 2030: Ending Poverty, Transforming All Lives and Protecting the Planet; Report №. A/69/700; United Nations General Assembly: New York, NY, USA, 2014, p. 34, available at: http://www.un.org/ga/search/view_doc.asp?sy $\mathrm{mbol}=\mathrm{A} / 69 / 700 \&$ Lang $=\mathrm{E}$.

[3] United Nations Development Program, Financing the 2030 Agenda-An Introductory Guidebook for UNDP Country Offices; UNDP: New York, NY, USA, 2018, available at: http://www.undp.org/content/undp/en/home/lib rarypage/poverty-reduction/2030-

agenda/financing-the-2030-agenda.html.

[4] Wieliczko B., Financial instruments - a way to support sustainable development of the EU rural areas? Case of Poland. Studia Ekonomiczne. Zeszyty Naukowe Uniwersytetu Ekonomicznego w Katowicach. Vol. 382, No. 16 (1), 2019, pp. 245-254.

[5] Raszkowski, A.; Bartniczak, B. Sustainable Development in the Central and Eastern European Countries (CEECs): Challenges and Opportunities. Sustainability, Vol. 11， 2019, pp. $1180, \quad$ available at: https://doi.org/10.3390/su11041180.

[6] Romanchukevich, V.V., Harmonization of the concept of sustainable development and public financial policy, Vcheni zapysky TNU imeni $V$. I. Vernadskoho. Seriia: Ekonomika $i$ upravlinnia, 30 (69). Vol. 6., 2019, pp. 126134. DOI: https://doi.org/10.32838/25234803/69-6-45.

[7] Raszkowski, A. and Bartniczak, B., On the Road to Sustainability: Implementation of the 2030 Agenda Sustainable Development Goals (SDG) in Poland, Sustainability, Vol. 11 (366). 2019, doi: 10.3390 / su11020366.

[8] OECD, Global Outlook on Financing for Sustainable Development 2019; OECD: Paris, France, available at: https://www.oecd.org/dac/financingsustainable-development/development-financetopics/ Global-Outlook-on-Financing-for-SD2019.pdf.

[9] European Commission. Financing a European economy, Final Report 2018 by the High-Level Expert Group on Sustainable Finance Secretariat provided by the European Commission, available at: https://www.buildup.eu/sites/default/files/conte $\mathrm{nt} / 180131$-sustainable-finance-finalreport_en.pdf.

[10] Elkington, J., Enter the Triple Bottom Line. Open Journal of Civil Engineering, Vol. 6 (5), 2004.

[11] Soini, K., \& Birkeland, I., Exploring the scientific discourse on cultural sustainability. Journal NorskGeografiskTidsskrift Norwegian Journal of Geography, Vol. 71 (3), 2014, pp. 27-31, available at: https://doi.org/10.1080/00291951.2017.134338 1.

[12] Shrithongrung, A., \& Kriz, K. A., The Impact of Subnational Fiscal Policies on Economic Growth: A Dynamic Analysis Approach. Journal of Policy Analysis and Management, 
33 (4), 2014, available at: https://doi.org/10.1002/pam.21784.

[13] Tudose, M. B, \& Rusu, V. D. Global Competitiveness of the European Union Member States: Evolution and Perspectives, Studies and Scientific Researches. Economic Edition. 22 (1), 201523-31.

[14] Dima, A. M., Begu, L., Vasilescu, M. D., \& Maassen, M. A., The relationship between the Knowledge Economy and Global Competitiveness in the European Union. Sustainability, Vol.10 (1706), 2018, pp.1-15, available at: https://doi.org/10.3390/su10061706.

[15] Donaires, O. S, Cezarino, L. O., Caldana, A. C. F., \& Liboni, L., Sustainable development goals - an analysis of outcomes. Kybernetes, 48 (1), 2019, pp. 183-207, available at: https://doi. org/10.1108/K-10-2017-0401.

[16] Patora-Wysocka, Z., \& Sułkowski, Ł., Sustainable Incremental Organizational Change - A Case of the Textile and Apparel Industry. Sustainability, 11(4), 2019, pp. 1-27, available at: https://doi. org/10.3390/su11041102.

[17] Gibney, J. Leadership of place and the dynamics of knowledge. In Leadership and Change in Sustainable Regional Development; Sotarauta, M., Horlings, L., Liddle, J., Eds.; Routledge, Regional Studies Association, Regions and Cities: New York, NY, USA, 2012, pp. 20-36.

[18] Diamond, J. Leadership and the voluntary and community sector. In Leadership and Change in Sustainable Regional Development; Sotarauta, M., Horlings, L., Liddle, J., Eds.; Routledge, Regional Studies Association, Regions and Cities: New York, NY, USA, 2012, pp. 80-102.

[19] Alinska, A.; Filipiak, B.; Kosztowniak, A. The Importance of the Public Sector in Sustainable Development in Poland. Sustainability, Vol.10, $2018,3278$.

[20] International Monetary Fund. World Economic Outlook (WEO) Database, available at: https://www.imf.org/en/Publications/SPROLLS /world-economic-outlook-databases\#sort= $\% 40 \mathrm{imfdate} \% 20 \mathrm{descending}$.

[21] Mature leader of the CEE region. EY's Attractiveness Survey Poland 2017, available at:

https://www.ey.com/Publication/vwLUAssets/ EY_Attractiveness_Survey_Poland_2017/\$FIL E/ EY-Attractiveness-Survey-Poland-2017.pdf.

[22] Comes, C.-A.; Bunduchi, E.; Vasile, V.; Stefan, D. The Impact of Foreign Direct Investments and Remittances on Economic Growth: A Case Study in Central and Eastern Europe. Sustainability, Vol.10, 2018, pp. 238.

[23] Cichowicz, E.; Rollnik-Sadowska, E. Inclusive Growth in CEE Countries as a Determinant of Sustainable Development. Sustainability, Vol. 10, 2018, pp.39-73.

[24] Raszkowski, A.; Sobczak, E. Delimitation procedure of degraded areas and the area targeted for revitalization. Econ. 21st Century, Vol.2, 2018, pp. 30-38.

[25] Vasconcellos O.R. Back to the Future: The Potential of Intergenerational Justice for the Achievement of the Sustainable Development Goals. Sustainability, Vol.10, 2018, pp. 427.

[26] OECD, Central and Eastern European Countries (CEECs), available at: https://stats.oecd.org/glossary/detail.asp?ID=30 3.

[27] Sustainable Development Report 2019, Transformations to achieve the SDGs, available at: https://www.iauhesd.net/sites/default/files/documents/2019_sus tainable_development_report-compresse.pdf.

[28] Sustainable Development Report 2020, The Sustainable Development Goals and Covid-19, available at: https://s3.amazonaws.com/sustainabledevelop ment.report/2020/2020_sustainable_developme nt_report.pdf.

[29] SDG Index and Dashboards Report 2018, Global Responsibilities, available at: https://s3.amazonaws.com/sustainabledevelop ment.report/2018/2018_sdg_index_and_dashbo ards_report.pdf.

[30] Eurostat. Database: Sustainable development indicators, available at: https://ec.europa.eu/eurostat/data/database/

[31] European Regional Development Fund, Funding Energy Efficiency through Financial Instruments. A Policy Brief from the Policy Learning Platform on Low-carbon economy, available

at: https://www.interregeurope.eu/fileadmin/user_ upload/plp_uploads/policy_briefs/TO4_Policy Brief_Financial_Instruments.pdf/

[32] Antonescu, D. Regional Development Policy in Context of Europe 2020 Strategy. Procedia Economics and Finance, Vol. 15, 2014, pp. 1091-1097, available at: https://doi.org/10.1016/S2212-5671(14)005619.

[33] Publications Office of the European Union, Sustainable development in the European Union, Overview of progress towards the SDGs 
WSEAS TRANSACTIONS on ENVIRONMENT and DEVELOPMENT DOI: 10.37394/232015.2021.17.86
Tetiana Kulinich, Natalia Yakimenko-Tereschenko,

Alla Melnyk, Alla Vasina, Viktoriia Adamyk

in an EU context, 2017 edition, available at: https://ec.europa.eu/eurostat/ documents/3217494/8461633/KS-04-17-780EN-N.pdf

Creative Commons Attribution License 4.0 (Attribution 4.0 International, CC BY 4.0)

This article is published under the terms of the Creative Commons Attribution License 4.0

https://creativecommons.org/licenses/by/4.0/deed.en -US 